\title{
PROGRESS ON THE PATERNAL BRAIN: THEORY, ANIMAL MODELS, HUMAN BRAIN RESEARCH, AND MENTAL HEALTH IMPLICATIONS
}

\author{
J.E. SWAIN \\ University of Michigan and Yale University \\ C.J. DAYTON \\ Wayne State University and University of Michigan \\ P. KIM \\ University of Denver \\ R.M. TOLMAN AND B.L. VOLLING \\ University of Michigan
}

\begin{abstract}
With a secure foundation in basic research across mammalian species in which fathers participate in the raising of young, novel brainimaging approaches are outlining a set of consistent brain circuits that regulate paternal thoughts and behaviors in humans. The newest experimental paradigms include increasingly realistic baby-stimuli to provoke paternal cognitions and behaviors with coordinated hormone measures to outline brain networks that regulate motivation, reflexive caring, emotion regulation, and social brain networks with differences and similarities to those found in mothers. In this article, on the father brain, we review all brain-imaging studies on PubMed to date on the human father brain and introduce the topic with a selection of theoretical models and foundational neurohormonal research on animal models in support of the human work. We discuss potentially translatable models for the identification and treatment of paternal mood and father-child relational problems, which could improve infant mental health and developmental trajectories with potentially broad public health importance.
\end{abstract}

RESUMEN: Con fundación segura en la investigación básica a través de las especies mamíferas en las que los padres participan en la crianza de sus pequeños, los novedosos acercamientos en el campo de imágenes cerebrales están definiendo un grupo de circuitos cerebrales consistentes que regulan los pensamientos y conductas paternas en los humanos. El más reciente paradigma experimental incluye cada vez más estímulos realistas al bebé para provocar percepciones y conductas paternas con medidas hormonales coordinadas para delinear las redes cerebrales que regulan la motivación, el cuidado reflexivo, la regulación de la emoción y las redes cerebrales sociales, con diferencias y similitudes a las que se presentan en las madres. En este artículo sobre el cerebro del padre, revisamos todos los estudios de imágenes cerebrales en PubMed hasta la fecha sobre el cerebro humano del padre e introducimos el tema con una selección de modelos teóricos y una básica investigación neuro-hormonal en modelos animales como apoyo al trabajo humano. Discutimos modelos potencialmente transferibles para la identificación y tratamiento de problemas de estado de humor y de relación padre-hijo, lo cual pudiera mejorar la salud mental infantil y las trayectorias de desarrollo con una potencial amplia importancia de salud pública.

RÉSUMÉ: Avec une fondation solide en recherches de base au travers des espèces de mammifères dans laquelle les pères participent à l'éducation des jeunes, des nouvelles approachs d'imagerie exposent un groupe de circuits du cerveau constants qui régulent les pensées paternelles et les comportements chez les humains. Les nouveaux paradigmes expérimentaux incluent des bébé-stimulus de plus en plus réalistes pour provoquer des cognitions et des comportements paternels avec des mesures d'hormones coordonnées afin de souligner les réseaux qui régulent la motivation, le soin réfléchi, la régulation de l'émotion et les réseaux sociaux du cerveau avec les différences et les similarités que l'on trouve chez les mères. Dans cet article sur le cerveau du père, nous passons en revue toutes les études d'imagerie cérébrale trouvées par le moteur de recherche PubMed qui existent sur le cerveau humain du père et nous présentons le sujet au moyen d'une sélection de modèles théoriques et de recherches en matière neurohomormonale fondamentale

This study was supported by grants from the National Alliance for Research on Schizophrenia and Depression/Brain and Behavior Foundation (JES), the Klingenstein Third Generation Foundation, NIMHD/NICHD RC2MD004767-01, the Michigan Institute for Clinical Health Research and the National Center for Advancing Translational Sciences, UL1TR000433 (JES, CJD), Robert Wood Johnson Health and Society Scholar Award (JES). We thank S. Shaun Ho for advice on the article. No author has a conflict of interest.

Direct correspondence to: J.E. Swain, Rachel Upjohn Building, 4250 Plymouth Road, Ann Arbor, MI 48109; e-mail: jamesswa@med.umich.edu.

INFANT MENTAL HEALTH JOURNAL, Vol. 35(5), 394-408 (2014)

(C) 2014 Michigan Association for Infant Mental Health

View this article online at wileyonlinelibrary.com.

DOI: $10.1002 / i m h j .21471$ 
chez des modèles animaux pour soutenir le travail sur l'humain. Nous discutons des modèles que l'on pourrait traduire pour l'identification et le traitement de l'humeur paternelle et les problèmes relationnels père-enfant, qui pourraient améliorer la santé mentale du nourrisson et les trajectoires de développement cela pouvant avoir à la clé une grande importance pour la santé publique.

ZUSAMMENFASSUNG: Mit einem sicheren Fundament in der Grundlagenforschung über Säugetierarten, tragen Väter zu der Entwicklung von jungen, neuartigen bildgebenden Ansätzen bei, indem eine Reihe von konsistenten neuronalen Verschaltungen skizziert wird, die väterliche Gedanken und Verhaltensweisen beim Menschen regulieren. Die neuesten experimentellen Paradigmen nutzen realistische Säuglings-Stimuli, um väterliche Kognitionen und Verhaltensweisen hervorzurufen, um mit abgestimmten Hormonerfassungen Netzwerke im Gehirn zu skizzieren, die Motivation, reflexive Fürsorge, Emotionsregulation und soziale Netzwerke im Gehirn regulieren. Diese sollen hinsichtlich Unterschieden und Ähnlichkeiten zu denen bei Müttern gefundenen Netzwerken betrachtet werden. In diesem Artikel zum Gehirn des Vaters, bieten wir einen Überblick über alle aktuellen bildgebenden Studien auf Pubmed über das menschliche Gehirn des Vaters und führen mit einer Auswahl von theoretischen Modellen und grundlegender neurohormonaler Forschung an Tiermodellen zur Unterstützung der menschlichen Arbeit in das Thema ein. Wir diskutieren potenziell übersetzbare Modelle für die Erkennung und Behandlung der väterlichen Stimmung und von Vater-Kind-Beziehungsproblemen, welche die psychische Gesundheit von Säuglingen und Entwicklungsverläufe mit potenziell großer Bedeutung für die öffentliche Gesundheit verbessern könnten.

ABSTRACT: 抄録:父親が幼い子育てに参加するほ乳類全体にわたる基礎研究での強固な基盤とともに、新しい脳画像アプローチによっ て、人類における父親の思考と行動を調節する一連の一貫した脳回路の輪郭が描かれつつある。母親に見られたものとの共通点と相違 点とともに、動機、リフレクティブな養育、情緒調節を調節する脳のネットワーク、および社会脳のネットワークの輪郭を描くため に、最新の実験パラダイムには、協調的なホルモンの測定とともに、父親の認知と行動を引き起こすための、ますます現実的な赤ちや んの刺激が含まれる。父親の脳についてのこの論文では、私たちは今日までの人間の父親の脳についての pubmed 研究をレビューする。そして、人間の研究を支援して、選択した理論的モデルと、動物モデルについての基礎的神経内分泌研究のト ピックを紹介する。私たちは、父親の気分と父子関係の問題を同定し治療するための、翻訳可能なモデルを考察する。それは、幅広い 公衆衛生の重要性を持つ可能性のある、乳幼児精神保健と発達の軌跡を向上させるだろう。

The interaction between the primary caregiver and the infant is among the most influential early environmental influences (Feldman, 2007). Building on the early work of Bowlby (1978), efforts to characterize this reciprocal interaction between parent and infant-especially for the mother-and assess its impact on infant and child development have provided a powerful theoretical and empirical framework in the fields of social and developmental psychology (Cassidy \& Shaver, 1999). In the last decade, psychologists have teamed with neuroscientists and brain-imagers to link parent-infant interactions with underlying brain physiology, with the goal of identifying new biomarkers for risk identification, improved mechanistic models, and ultimately, improved biologically rooted therapies. With much of the work so far focused on the mother brain (Barrett \& Fleming, 2011; Swain, 2011; Swain, Kim, \& Ho, 2011; Swain, Kim et al., 2014), this article focuses on the existing work on the father brain, using imaging and hormone measures that are just beginning to be placed in useful theoretical frameworks which are themselves under development.

In an effort to conceptualize and empirically test fathering behaviors and the mechanisms that account for their influence on child developmental outcomes, Lamb, Pleck, and colleagues developed one of the first and still-evolving models (Lamb, 1976; Lamb, Pleck, Charnov, \& Levine, 1985; Pleck, 2010). This model conceptualizes father involvement as comprised of three primary and two auxiliary domains central to fathering-some of which coincide with existing research on the mother-child relationship. The primary domains include: (a) positive and direct engagement (e.g., play, soothing) with the child in ways that promote healthy development, (b) parental warmth and responsiveness directed toward the child, and (c) activities that serve to monitor and make decisions on behalf of the child to control his or her environment. Auxiliary domains include: (d) indirect care such as arranging for childcare and medical care, and (e) process responsibility that includes monitoring activities to ensure that the child's needs within the first four domains are being met.

Indeed, empirical research has demonstrated important facets of father-child interactions that appear to be unique to fathers (vs. mothers) beginning in infancy (Crawley \& Sherrod, 1984; Feldman, 2003). Fathers, for example, tend to exhibit predominantly physical interactions with their young children, often characterized as "rough-and-tumble" play (Carson, Burks, \& Parke, 1993). Furthermore, within father-child relationships, it may be the quality of active, parent-child play interactions and not sensitivity, per se, that is related to positive socioemotional outcomes in children, such as interpersonal confidence and the development of positive peer relationships (MacDonald, 1987). Volling, McElwain, Notaro, and Herrera (2002) found that fathers' physically playful interactions with their 1-year-old infant were significantly related to more expressed infant positive affect whereas this was not the case when mothers engaged in physical play. This is in accord with work on the father's role as the "primary playmate" (Roggman, Boyce, Cook, Christiansen, \& Jones, 2004), in which father-toddler social toy play predicted better cognitive and social developmental outcomes for young children, especially in an Early 
Head Start group. Thus, fathers may be uniquely attuned to certain aspects of the emotional states of their infants during bouts of physical activity, which ultimately contribute to young children's early emotion regulation. These findings have suggested that mechanisms in fathers-different from mothers-may account for the establishment and maintenance of the father-child relationship and warrant research specific to fathers.

Building on the notion from attachment theory, that both attachment and exploration systems are developing in the infant and young child, Paquette (2004) proposed an alternative theory of the father-child attachment relationship, termed the activation relationship theory. This theory includes two dimensions of fathering that underlie the father-child relationship: (a) stimulation, wherein fathers encourage the child's interaction with the outside world; and (b) discipline designed to provide children with limits that will maintain their safety. Through these stimulating interactions, dimensions of social competencies (cooperation vs. competition) are linked to various dimensions of parenting (e.g., caregiving, make-believe, physical play). In short, the father-child activation relationship would appear to help children to be braver when they encounter new experiences, which may later enable them to overcome obstacles to their personal success (and ultimately to their survival and reproductive success) (Paquette, 2004).

As the theoretical and empirical literature has advanced our understanding of fathering behaviors, interest in the factors contributing to these behaviors has emerged. For example, Cabrera, Fagan, and Farrie (2008) and Cabrera and Tamis-LeMonda (2013) developed a comprehensive model of father involvement that includes mechanisms underlying the development and maintenance of fathering behaviors within cultural and family contexts. These researchers proposed three factors that underlie the expression of fathering behaviors: (a) the father's own early relationship ("rearing") history, (b) the cultural context in which the father was raised, and (c) the father's biological history and makeup. These factors are proposed to influence fathering characteristics that are predictive of father involvement within particular family and social contexts and, ultimately, predict children's psychosocial and behavioral outcomes.

Although theoretical models of fatherhood have made substantial progress over recent decades, they have yet to consider paternal health issues (addressed later in this review) for father or infant as either cause or effect. In addition, fatherhood models have yet to be integrated with an emerging neurobiological literature on nonhuman fathers that foreshadows the discovery of parallel biological mechanisms in humans. Specifically, becoming a father has become known to involve a major neurohormonal reorganization that prepares for the expression of adequate caregiving (Storey, Walsh, Quinton, \& Wynne-Edwards, 2000) across mammalian species.

\section{EVOLUTION AND ANIMAL MODELS OF PATERNAL CARE}

Pregnancy and childbirth are obviously associated with marked changes in maternal physiology, with brain areas implicated in motivation, nurturance, and attention (Kinsley \& Amory-Meyer, 2011). Research in biparental species has pointed to alterations in fathers' brains, contingent upon exposure to infant cues (Franssen et al., 2011). From an evolutionary perspective, paternal versus maternal roles are distinct (Kinsley \& Amory-Meyer, 2011), yet they may share underlying physiological mechanisms. Paternal care is observed in only 3 to $5 \%$ of mammalian species which have provided interesting animal models of fatherhood that are still in the early years of study.

For example, research on the biparental California mouse Peromyscus californicus has demonstrated that the father actively participates in raising his young with long-term behavioral consequences for offspring, including hormone regulation, and a range of behaviors from a body of work by Marler and colleagues (Becker, Moore, Auger, \& Marler, 2010; Bester-Meredith \& Marler, 2001, 2003; Frazier, Trainor, Cravens, Whitney, \& Marler, 2006; Gleason \& Marler, 2013). Furthermore, for rats, the amount of experience interacting with their pups correlates with the neuronal development of the hypothalamus, basolateral amygdala, parietal cortex, and prefrontal cortex (PFC) (Featherstone, Fleming, \& Ivy, 2000; Lonstein, Simmons, Swann, \& Stern, 1998; Xerri, Stern, \& Merzenich, 1994). For prairie voles, those exhibiting biparental care show increased c-Fos expression in the medial preoptic area (MPOA) (Kirkpatrick, Carter, Newman, \& Insel, 1994), which is critical for paternal behaviors (Rosenblatt \& Ceus, 1998).

Involvement of the father in parental care in primates is perhaps best demonstrated in marmosets, where fathers display extensive care behaviors toward their young. Among possible sources of variation in paternal care are the roles of circulating gonadal hormones, and genetic relatedness with the extent of paternal care in male parents has been shown to be inversely correlated with circulating testosterone and cortisol levels and positively correlated with the genetic relatedness between infants and the father (Nunes, Fite, Patera, \& French, 2001). More recent work in this model also has highlighted offspring care experience increasing grooming and shaping consistent food-sharing patterns with infants (Cavanaugh \& French, 2013). Marmosets also have a unique embryonic development in which a shared blood supply results in the exchange of stem cells between fraternal twins (Haig, 1999), which then differ in genetic relatedness. Studies in such families found that fathers who have a greater relatedness exhibit differing paternal care accordingly with effects on key developmental parameters, including puberty and adult stress response (Ross, French, \& Orti, 2007). The transition to fatherhood was associated with higher density of marmoset PFC (Kozorovitskiy, Hughes, Lee, \& Gould, 2006a), suggesting an interesting brain area for further study in the regulation paternal behaviors. Thus, animal models of fatherhood provide a rich source for studying the interrelationships among early experience, hormones, and genes over the course of development.

\section{EXPLORING HUMAN FATHER PHYSIOLOGY}

Partly following the norm in most human cultures for the mother to care for the young children, studies of parent-infant 
interactions have historically targeted the mother-child relationship. As the press for greater caregiving responsibility for fathers has increased, due to increasing numbers of women working fulltime, more recent research has closely examined father-infant interactions and has reported that fathering also plays a significant role for the child's cognitive, emotional, and social development (Lamb, 2004; Ramchandani \& Psychogiou, 2009; Swain, 2009). For example, literature examining parental behaviors has supported parental gender differences in expressed emotion during interactions with children (Volling et al., 2002). Specifically, maternal sensitivity is typically expressed by emotional warmth and support whereas paternal sensitivity, consistent with Paquette's (2004) model, frequently manifests as the provision of stimulating, physically playful interactions (Grossmann, Grossmann, Kindler, \& Zimmermann, 2008).

The ability to examine sex differences in parenting is enhanced when parents of the same child individually engage in standardized parenting protocols. In this case, family and culturalcontext characteristics can be held relatively stable, allowing for the direct comparison of fathering and mothering behaviors. An example of the use of this methodology is a study that has used a time-series analysis of 100 first-time mothers and fathers interacting with their 5-month-old firstborn child (Feldman, 2003). Mother-child play was characterized by face-to-face exchanges and included patterns of mutual gazing, co-vocalization, and affectionate touch. In contrast, and consistent with Paquette's (2004) model, during play with fathers, a pattern of interactive arousal was identified that contained several quick peaks of high positive emotionality, including joint laughter and open exuberance. Such specialization of father-infant interactions is consistent with play studies showing more object-oriented or physical play associated with child smiles, as compared with mother-infant interactions (Dickson, Walker, \& Fogel, 1997; Feldman, 2003; Lamb, 1977; Yogman, 1981). Thus, unique contributions from father-child interactions (Boyce et al., 2006; Grossmann et al., 2002) to evolutionarily favorable sex-specific emotional expressions of the developing child have been argued to propagate sex differences in the expression of emotion (Vigil, 2009) across generations.

The differential nature of father- versus mother-child relationship characteristics suggests that the underlying neurobiology of fathering behaviors may in some ways be distinct from that of mothers. For example, certain infant signals may activate father brains more strongly than they do mother brains. This kind of a response could underlie paternal capacity and motivation to effectively assess external contextual factors to determine whether situations are sufficiently safe to encourage the child's engagement and interactions with the broader social environment. In contrast, hormonal changes corresponding to the perinatal period may result in a stronger reflexive caring response for mothers. Finally, empathic/mentalizing cognitive responses to infant cues may be similar for mothers and fathers, as it supports all types of parenting responses and behaviors-at least after an initial period of adaptation of some months after the infant's birth. This area is not well-studied, but it is in keeping with the observation that fathers and mothers were equally able to correctly identify own versus other baby-cry (Swain, Leckman, Mayes, Feldman, \& Schultz, 2005; Swain \& Lorberbaum, 2008).

Indeed, the status of fatherhood versus nonfatherhood may be associated with certain experiences under hormone regulation. For example, Fleming, Corter, Stallings, and Steiner (2002) found that fathers hearing baby cry stimuli felt more sympathetic and more alert as compared to nonfathers who heard the cries, and testosterone and prolactin were key mediators of paternal responses. Specifically, fathers and nonfathers with lower salivary testosterone levels had higher sympathy and/or need to respond to the infant cries than did fathers with higher testosterone levels. Interestingly, first-time fathers, as compared to experienced fathers, showed increased levels of testosterone, which contributed to heightened physiological (heart rate) and emotional responses to infant cries. The increased testosterone among first-time versus experienced fathers can be understood as greater attention and anxiety in response to infant cries that are more common in first-time parents. On the other hand, serum prolactin levels were higher with paternal alertness and positive response to the cries, and experienced fathers hearing the cries showed a greater percentage increase in prolactin levels, as compared to first-time fathers or to any group of fathers hearing control stimuli. These data are consistent with notions of baby cry-parental care behavioral loops, which may be a function of experience (Swain, Mayes, \& Leckman, 2004).

These results are particularly interesting in light of the convergent findings that men and women have similar stage-specific differences in hormone levels, including higher concentrations of prolactin and cortisol in the period just before the births and lower postnatal concentrations of sex steroids (testosterone or estradiol). Fathers in general have less testosterone than do nonfather males (Gray, Yang, \& Pope, 2006). Indeed, men with more pregnancy symptoms (couvade) and men who were most affected by the infant reactivity test had higher prolactin levels and greater postbirth reduction in testosterone (Storey et al., 2000). Thus, testosterone levels are emerging as related to lifehistory trade-offs, such as those involving fatherhood, because lower testosterone is linked to lower sexual and mating activity (Gettler, McDade, Agustin, Feranil, \& Kuzawa, 2013). These findings have stimulated work on hormones related to paternal behavior.

Cardiovascular measures, prolactin, oxytocin, progesterone, and estrogen have been under study as related to father-infant behavior. At 6 months' postpartum, paternal prolactin and oxytocin have been shown to be related to father-infant coordinated exploratory play in a toy context and affect synchrony in a social interaction context, respectively (Gordon, Zagoory-Sharon, Leckman, \& Feldman, 2010). In related experiments, progesterone was also associated with father-child interactions (Gettler, McDade, Agustin, \& Kuzawa, 2013). Furthermore, in agreement with a trend to include more comprehensive physiological measures, cardiovascular parameters and hormones were measured before and after a 
30-min father-infant play session at 22 months' postpartum. Overall, heart rate, blood pressure, prolactin, testosterone, and cortisol levels tended to decrease, but in a manner dependent on contextual factors such as amount of recent father-infant interaction and extent of maternal interactions (Storey, Noseworthy, Delahunty, Halfyard, \& McKay, 2011). In similar studies using 30-min play sessions of fathers with their toddlers, progesterone and estrodial also decreased at a greater rate for fathers of infants and fathers with more than one child, respectively (Gettler, McDade, Agustin, \& Kuzawa, 2011). Further, Gettler and colleagues found decreases in testosterone in a longitudinal investigation of men who became fathers compared to those who did not (Gettler, McDade, Agustin, Feranil, \& Kuzawa, 2013), and Kuo, Saini, Thomason, Schultheiss, and Volling (in press) also found that decreases in men's testosterone while observing their infant in distress during a lab-based assessment of infant-father attachment predicted sensitively responsive and cognitively stimulating fathering behavior in subsequent father-infant interactions. These studies of parental paternal hormones foreshadow work on the hormone-sensitive brain circuits that regulate parenting thoughts and behaviors-every one of which listed in PubMed to date is reviewed here.

\section{HUMAN FATHER BRAIN}

Preliminary work on the brain physiology of human fathers is new enough for us to cover all articles listed in PubMed to this point (Table 1) that have employed magnetic resonance imaging (MRI) methodology. In brief, subjects lie in a magnet on a table and have images and sound projected to them while brain activity is measured using radio-frequency signals and strong magnetic fields that take advantage of a how metabolic activity leaves a measurable magnetic signature (Swain \& Lorberbaum, 2008).

We begin with research that involved both mothers and fathers. With a sample of coparent couples of 4- to 6-month-old infants and own-infant (vs. other infant) video clips, Atzil, Hendler, Zagoory-Sharon, Winetraub, and Feldman (2012) found greater activation in areas important for social cognition (insula, prefrontal cortical regions) and empathy (cortical regions) for both mothers and fathers. However, plasma oxytocin (OT) for mothers was correlated with responses in motivation circuits, yet for fathers was correlated with own- versus other-infant comparisons, primarily with cognitive areas - including areas that are responsible for regulating and organizing behavioral responses to emotionally salient stimuli (e.g., dorsolateral prefrontal cortex [dlPFC], dorsal anterior cingulate $[\mathrm{ACC}])$. Finally, activation in a key salience/motivation region (amygdala) was correlated with OT in mothers, but rather vasopressin (VP) in fathers. These results show considerable overlap in circuit response with apparent differences which may eventually be tied back to aspects of father behavior such as the social play highlighted by Roggman et al. (2004) and sex differences in hormone regulation of behavior in mouse models of fatherhood (described earlier).

Another functional MRI study including both parents and nonparents found that males responded differently to the hunger cries of infants than did females (De Pisapia et al., 2013). In a comparison of the "listen to cry sound" versus the resting condition, females, as opposed to males, exhibited greater deactivations in the dorsal medial prefrontal and posterior cingulate areas, which are a part of the default mode network and involved in mind-wandering and self-reflection (Buckner, Andrews-Hanna, \& Schacter, 2008). The deactivation in the default mode network is considered to be important when individuals are paying attention to a task or stimuli from outside. Thus, the neural differences between genders may be interpreted as greater difficulty shifting attention to infant cries in males than in females (De Pisapia et al., 2013).

Using similar methodology and a sample of young infants (8-19 weeks old), the brain responses of fathers to own versus other infant videos were studied (Kuo, Carp, Light, \& Grewen, 2012). Increased neural responses to own infant stimuli were similar to ones observed in mothers (Barrett \& Fleming, 2011; Swain, 2011; Swain, Mayes et al., 2004). Whole-brain analysis demonstrated increased activity in emotion-regulation circuits, including bilateral inferior frontal gyrus (IFG), and the empathic/mentalizing networks including supramarginal (parietal) gyrus and bilateral middle temporal gyrus among human fathers $(N=10)$ in response to own- (vs. other-) baby stimuli. In addition, on the contrast of baby (both own and other babies) versus doll video contrasts, fathers exhibited increased activity in many social brain networks, including sensory/salience, reflexive caring, emotion regulation, and empathic/mentalizing regions, including bilateral caudate, orbitofrontal gyrus (OFC), superior frontal gyrus, and superior parietal lobe. Again, these findings are similar to ones in mothers in response to infant stimuli. Activation of these systems plausibly supports a father's ability to attend to the infant and the surrounding environment and react as necessary to promote infant-environment interactions or to protect the infant from environmental dangers. Interestingly, a different neural pattern of activation in fathers also was observed in this study. Previously, increased OFC response to infant stimuli was observed in mothers (Parsons, Stark, Young, Stein, \& Kringelbach, 2013). However, in fathers, lower responses to own(vs. other-) baby stimuli in the OFC was associated with greater paternal sensitivity observed during father-infant interactions. The findings may reflect the unique role of the OFC in interpretation of the uncertainty about their own babies and parenting among fathers.

Using infant photographs instead of video clips to stimulate father brains, Wittforth-Schardt et al. (2012) found activations for own child in the left globus pallidus (GP), the left hippocampus, the right medial OFC, regions involved in emotion regulation, and in the bilateral IFG/anterior insula, involved in social information processing, and activations for own child versus other (unknown) child in the right GP, the left ventral tegmental area (VTA), the left medial OFC, and the left IFG/anterior insula, important for parental motivation. Furthermore, in the first father-brain study to do so, intranasal oxytocin, a hormone critical for parental bonding with their children, was administered and shown to reduce activation and functional connectivity of the left GP with reward- and 
TABLE 1. Functional and Structural Brain-Imaging Studies of Fathers With Main Brain-Circuit Findings

\begin{tabular}{|c|c|c|c|c|}
\hline Author(s) (Year) & $N$ Group & Age of Infants or Children & Brain-Imaging Paradigm & Brain-Circuit Findings \\
\hline \multicolumn{3}{|l|}{ HEALTHY FATHERS } & \multicolumn{2}{|l|}{ Baby Visuals } \\
\hline $\begin{array}{l}\text { Swain et al. (2005); } \\
\text { Swain et al. (2008) }\end{array}$ & $9-14$ & 2-4 Weeks \& 3-4 Months & $\begin{array}{l}\text { Own vs. Other, Experience \& } \\
\text { Thoughts }\end{array}$ & $\begin{array}{l}\uparrow \text { Motivation/reward circuits, emotion } \\
\text { regulation, empathy }\end{array}$ \\
\hline Atzil et al. (2012) & 15 & 4-6 Months & Own videos, Synchrony, OT & $\begin{array}{l}\uparrow \text { Socioemotional information processing; } \\
\text { motivation response related to hormone } \\
\text { vasopressin }\end{array}$ \\
\hline Kuo et al. (2012) & 10 & 2-4 Months & $\begin{array}{l}\text { Own vs. Other videos, Baby } \\
\text { vs. Doll videos }\end{array}$ & $\begin{array}{l}\uparrow \text { Emotion regulation and social information } \\
\text { processing }\end{array}$ \\
\hline $\begin{array}{l}\text { Wittfoth-Schardt et al. } \\
\text { (2012) }\end{array}$ & 21 & 3-6 Years & $\begin{array}{l}\text { Own vs. Other Child Photos } \\
\text { and OT }\end{array}$ & $\begin{array}{l}\uparrow \text { Emotion regulation and empathy }+ \text { altered } \\
\text { connectivity with hormone oxytocin }\end{array}$ \\
\hline \multirow[t]{2}{*}{$\begin{array}{l}\text { Mascaro, Hackett, \& } \\
\quad \text { Rilling (2013) }\end{array}$} & \multirow[t]{2}{*}{70} & \multirow[t]{2}{*}{$1-2$ Years } & $\begin{array}{l}\text { Own vs. Other images, } \\
\text { Measure T, Father-Behav }\end{array}$ & \multirow[t]{2}{*}{$\begin{array}{l}\uparrow \text { Motivation and emotion regulation }+ \text { inverse } \\
\text { relation to testicle volume and testosterone }\end{array}$} \\
\hline & & & Baby Cry & \\
\hline Seifritz et al. (2003) & 10 & $<3$ Years & Other vs. Control, +ve/-ve & $\begin{array}{l}\uparrow \text { Motivation, emotion regulation, empathy for } \\
\text { fathers (combined with mothers) vs. } \\
\text { nonparents }\end{array}$ \\
\hline $\begin{array}{l}\text { Swain et al. (2003); } \\
\text { Swain, Leckman et al. } \\
\text { (2004); Swain et al. } \\
\text { (in press) }\end{array}$ & 9 & 2-4 Weeks \& 3-4 Months & $\begin{array}{l}\text { Own vs. Control Sound, } \\
\text { Experience \& Thoughts }\end{array}$ & $\begin{array}{l}\uparrow \text { Emotion regulation related to paternal } \\
\text { sensitivity }\end{array}$ \\
\hline $\begin{array}{l}\text { Mascaro, Hackett, } \\
\text { Gouzoules et al. } \\
\text { (2013) }\end{array}$ & 36 & 1 or 2 Years & Other Baby-Cry vs. Control & $\begin{array}{l}\uparrow \text { Emotion regulation and empathy related to } \\
\text { androgen receptor genes and caregiving }\end{array}$ \\
\hline De Pisapia et al. (2013) & $\begin{array}{l}9 \mathrm{M}+9 \mathrm{~F}(\text { not } \\
\text { parents) }\end{array}$ & 1 Year & Other Hunger Cry vs. Rest & Attention shifting (males $<$ females) \\
\hline Kim et al. (2014) & 16 & 2-4 Weeks \& 3-4 Months & $\begin{array}{l}\text { Structural }=\text { No Stimulus } \\
\quad \text { Voxel-Based Morphometry }\end{array}$ & $\begin{array}{l}\uparrow \text { Volumes in motivation/reward regions } \\
\text { inversely with depression over first } 4 \\
\text { months' postpartum }\end{array}$ \\
\hline
\end{tabular}

attachment-related regions responsive to pictures of both own and unfamiliar children. This is a key article connecting the administration of a hormone that regulates social behavior with parental brain-circuit activity.

In another fascinating study of father-brain parenting mechanisms, own versus other child versus adult pictures were used as stimuli 1 to 2 years' postpartum (Mascaro, Hackett, \& Rilling, 2013). In this study, there was a main effect for child versus adult pictures in the fusiform gyrus, dlPFC, thalamocingulate, and mesolimbic areas - fitting with reflexive caring parental-brain circuits also characterized in animal research (Swain, Lorberbaum, Kose, \& Strathearn, 2007). In addition, testosterone was the hormone of interest and was shown to be directly related to testicular volume, a potential indicator of lower reproductive activity, and inversely related to VTA responses to child images and parental sensitivity. The findings have supported that fathers may gradually develop a strong attachment with their infants over the course of the first and second years, and the attachment-building processes may be supported by neurobiological adaptations such as increased neural sensitivity to own infants and decreased testosterone levels.

Furthermore, variations in the androgen receptor gene among fathers 1 to 2 years' postpartum were associated with activations in
IFG and OFC - areas also involved in empathy and emotion regulation (Mascaro, Rilling, Negi, \& Raison, 2013; Mascaro, Rilling, Tenzin Negi, \& Raison, 2013), in response to infant cries from 3 to 5 months' postpartum (Mascaro, Hackett, Gouzoules, Lori, \& Rilling, 2013). Anterior insula activity exhibited a nonlinear relationship with paternal caregiving, such that fathers with intermediate activation were most involved in parenting activity. These results have suggested that restrictive attitudes may be associated with decreased empathy and emotion regulation in response to a child in distress, and that moderate anterior insula activity reflects an optimal level of arousal that supports engaged fathering.

Going back 12 years and using a variety of baby-cry stimuli types and durations, including 30-s blocks of discomfort cry versus control noise (Swain et al., 2003; Swain, Leckman et al., 2004) to activate emotion regulation and motivation regions according to caring thoughts and behaviors, similar results have been foundeven when lumping mothers and fathers versus nonparents, there is increased activity in the amygdala to 6-s episodes of baby cry and laughter (Seifritz et al., 2003) in emotion response, regulation, and empathy regions.

Finally, father-brain structure also is under study based on animal models (Kinsley \& Lambert, 2008) and indicates neural 
plasticity in human fathers during early postpartum period. Previously, there was a neuroimaging report on grey-matter volume increases in a number of brain regions of human mothersincluding the striatum, thalamocingulate, and PFC from the first to the fourth month' postpartum (Kim et al., 2010). For new fathers, several similar regions - the striatum, thalmocingulate, and later PFC - show grey matter increases from the first to fourth month' postpartum (Kim et al., 2014) — a finding in accord with research on marmosets (Kozorovitskiy, Hughes, Lee, \& Gould, 2006b). Furthermore, increases in grey-matter volume over this period in the left striatum were associated with fewer depressive symptoms at the fourth month' postpartum. However, unlike findings in mothers, fathers showed a decrease in grey matter in brain regions, and particularly, decreases in grey-matter volume in the right OFC were associated with how physically intrusive the fathers were at the fourth month' postpartum. However, given that physical activity and stimulation are a typical characteristic of father-child play, decreases in grey-matter volume in the OFC, involved in emotion and stress regulation, may in fact be associated with fathers' increased physical and playful play with their children. The findings have provided evidence for neural plasticity in fathers' brains over the early postpartum months that may help identify biomarkers for risk, resilience, and intervention.

Taken together, these studies have demonstrated father-brain responses to baby stimuli in regions that map broadly well onto maternal brain-response models that include sensory/motivation, reflexive caring, emotion regulation, and social cognitive networks (Swain, Kim et al., 2014). There are interesting differences emerging, however, that may reflect different parenting roles. Future research with more sophisticated paradigms such as simulated infants (van Anders, Tolman, \& Volling, 2012) and multimodal brain imaging may improve the understanding of brain mechanisms that regulate father behavior that may translate to circumstances of father mood disorders.

In humans, imaging studies have suggested a model with at least four global networks underlying maternal care, also largely important for the regulation of paternal care: (a) arousal, sensory processing, recognition, and motivation centers, including sensory cortices, amygdala, and ventral striatum; (b) a basic reflexive caring system that we share with many species that includes the hypothalamus and interconnected regions including the ventral portion of the bed nucleus of the stria terminalis, the MPOA, the lateral septum, and certain monoaminergic brainstem nuclei such as the dopaminergic ventral tegmental area and the noradrenergic locus ceruleus nearby regions; (c) an emotional regulation network that includes the medial prefrontal cortex and the ACC connecting to limbic regions; and (d) a social-attention network implicated in social cognition and empathy that includes superior temporal gyrus, insula, dlPFC, and OFC (Swain, Kim et al., 2014). The dynamic coordination of these circuits underlies the parent's ability to read the infant's nonverbal signals and to provide synchronous, attuned, and reflective parenting; in contrast, malfunction in these circuits may occur in maternal psychopathology (Moses-Kolko, Horner,
Phillips, Hipwell, \& Swain, 2014) and also perhaps paternal depression (discussed later).

Recent studies have begun to address whether the neurobiology of human fatherhood involves similar integration of limbic and cortical networks and whether it is mediated by processes related to pair bonding as it is in mothers. Theoretical work to date has suggested differences in the neurohormonal functioning of fathers versus mothers, and extant empirical literature has pointed to both similarities and differences in the underlying neurobiology of fathering, as compared to mothering (Paquette, 2004). This is a matter that bears important implications for the study of human attachment for fathers, the assessment of associated risks, and formulation of interventions to improve infant mental health. The current review will examine the research to date that informs our understanding of these processes. Specifically, research using animal models of fathering and studies examining the neurobiology of human fathering will be reviewed. Research that best informs our understanding of actual or potential fathering behaviors in humans was selected for this review. The case of postpartum depression (PPD) in human fathering then will be considered; this emerging area of research informs an understanding of fathering within a particular risk context. Finally, fathering influences on early child development, with an emphasis on biological development, are explored.

The summary table lists these brain imaging studies of fathers.

\section{UNDERSTANDING POSTPARTUM PATERNAL MOOD DISTURBANCES}

PPD has been mostly perceived as a problem limited to women with a newborn baby and has not included men. Indeed, research accumulated over the past 50 years has focused on the biological and environmental features associated with maternal PPD in an effort to mitigate the increasingly clear, deleterious impact on child development (Brockington, 2004; Kim \& Swain, 2007; Miller, 2002; Ramchandani, O'Connor et al., 2008). Studies have suggested that paternal PPD also has significant prevalence and impact on father's positive support for both a mother and baby during the first postpartum year. Indeed, the postnatal experience poses many challenges to men's as well as women's lives and mental health (Rutter et al., 2004; St John, Cameron, \& McVeigh, 2005). The timing and details of paternal PPD are just recently beginning to be recognized, studied (Matthey, Barnett, Howie, \& Kavanagh, 2003; Paulson \& Bazemore, 2010; Paulson, Dauber, \& Leiferman, 2006; Ramchandani, Stein, Evans, O'Connor, \& the Alspac Study Team, 2005), and placed into a biological framework that could involve the brain. The study of PPD in men offers a specific context in which to understand the neurobiology of fathers when a known risk factor is present.

Estimates of fathers' depression during the first postpartum year among U.S. community-based samples and using different interview tools vary from $4 \%$ (Ramchandani et al., 2005) to 25.5\% (Soliday, McCluskey-Fawcett, \& O'Brien, 1999), with a 
meta-analytic estimate of $10.4 \%$ (Paulson \& Bazemore, 2010). Internationally, the rate of paternal PPD ranges from 1.2\% (Lane et al., 1997) to $11.9 \%$ (Pinheiro et al., 2006). The wide range of estimates of paternal PPD may be related to the use of different measures, different cutoff scores, and different timing of assessments between studies as well as social, cultural, and economic differences. The characteristics of different samples also might be associated with different rates of depression. For instance, firsttime fathers report higher levels of anxiety during the early postpartum period (Gjerdingen \& Center, 2003; Kim, Mayes, Feldman, Leckman, \& Swain, 2013; Quinlivan \& Condon, 2005). Consensus has not yet been reached for diagnostic criteria for PPD, although many agree that the time course for postpartum paternal depression seems to lag behind maternal depression by several months, with maternal depression being the major risk factor for paternal depression in the perinatal period, but that current interview tools require revision for accurate assessment of fathers (Kim \& Swain, 2007).

The transition to becoming a new parent can be a stressful experience for both men and women. Gjerdingen and Center (2003) found that fathers and mothers both reported decreasing relationship satisfaction due to the lack of support they experienced and to their reported unstable mental states during the first 6 months after a child was born (Gjerdingen \& Center, 2003). Even in the absence of psychopathology, paternal anxiety does increase in the postpartum (Kim et al., 2013; Leckman et al., 1999). If severe, a father's anxiety and depression may go beyond evolutionarily survival-promoting levels (Feygin, Swain, \& Leckman, 2006) and translate into violent behaviors toward his partner. Among mothers in the postpartum period, an alarming one fourth reported violence from their partners, with $69 \%$ being the first occurrence (Hedin, 2000). Given the importance of the partner's psychological support as a protective factor for PPD (Rutter et al., 2004), low support from fathers who experience PPD may cause a mother to become more vulnerable to stress and psychopathology (Morse, Buist, \& Durkin, 2000). As described earlier, the PFC is specifically implicated in paternal PPD (Kim et al., 2014), suggesting that future research should examine the role that paid leave plays in the functioning of this area as well as the possibly beneficial effects of interventions.

\section{PATERNAL BRAIN: IMPLICATIONS FOR THE INFANT}

The poor mental health of the partner of a father with PPD likely also affects infant development. In fact, the moderate levels of comorbidity between maternal and paternal PPD of 0.31 (Paulson \& Bazemore, 2010) suggests considerable risk for an infant to be in a situation where both parents are depressed. Under such conditions, infants receive undesirable parent health behaviors on feeding and sleep, and fewer positive parent-infant interactions (Paulson et al., 2006). On the other hand, the protective role of paternal care may become more important when a mother is depressed. One study has shown that responsive care provided by the father can actually buffer an infant from being negatively influenced by maternal
PPD during development (Hossain et al., 1994). A growing body of recent studies has suggested that in interacting with infants, fathers exhibit capabilities to interact with their infants almost as well as do mothers (Feldman, 2003; Solantaus \& Salo, 2005). The quality of paternal care is clearly important for a child's cognitive, emotional, and social development during the first years and likely beyond (Pruett, 1998, 2000; Ramchandani et al., 2005).

For each infant, the first year is a critical period of forming basic biological and behavioral regulatory patterns through interactions with primary caregivers (Polan \& Hofer, 1999; Swain et al., 2012). An infant's heightened levels of the stress hormone cortisol resulting from unresponsive or chaotic parenting can hamper normal brain growth and self-regulatory ability in the early life (Cicchetti \& Rogosch, 2001). In addition, a chronic elevation of basal cortisol levels affects an infant's physiological growth and immune system (Federenko \& Wadhwa, 2004). In fact, negative interactions between a depressed parent and infant might interrupt the maturation of the infant's orbitofrontal cortex, which plays an important role in cognitive and emotional regulation throughout life (Schore, 2005).

The first year also is an important time for an infant to establish a secure attachment with his or her parents. Depressed parents tend to exhibit negative emotions and helplessness, which can influence their interactions with the infant. For instance, depressed mothers exhibit more irritability, apathy, and hostility toward their infants (Martins \& Gaffan, 2000). Some findings have suggested that the link between unresponsive and unaffectionate parenting of both mothers and fathers may contribute to the development of insecure attachments (Eiden, Edwards, \& Leonard, 2002). An insecure attachment with a depressed mother is associated with the development of emotional and behavioral problems as well as the risk of psychopathology (Martins \& Gaffan, 2000). Similarly, paternal depression has a significant and deleterious effect on paternal behaviors (Ramchandani, O'Connor et al., 2008; Ramchandani et al., 2005; Ramchandani, Stein et al., 2008; Wilson \& Durbin, 2010) and has been linked to the harsh physical discipline of infants (Davis, Davis, Freed, \& Clark, 2011).

The effects of paternal PPD on infant development seem to interact with maternal mood, and may indeed have long-term repercussions. Recent studies have found that children with fathers experiencing PPD tend to exhibit greater behavioral problems such as conduct problems or hyperactivity. Such negative impacts of paternal PPD on behavioral regulation were found to be stronger among boys than girls (Ramchandani, O'Connor et al., 2008; Ramchandani et al., 2005; Ramchandani, Stein et al., 2008), but also were present in girls (Rohde, Lewinsohn, Klein, \& Seeley, 2005), and to aggravate the negative impact of maternal depression (Mezulis, Hyde, \& Clark, 2004).

Consistent with ecological models of human development (Bronfenbrenner, 1979), new demands and responsibilities during the postpartum period often cause major changes in a father's life and impact family systems. Fathers may experience unique difficulties in developing emotional bonds with their child, as compared with mothers who arguably have more clear evidence of the 
arrival of their child through pregnancy — although the inclusion of fathers in prepartum ultrasounds may decrease this phenomenon (Walsh, Singh, Davis, Palladino, \& Tolman, 2014). The fatherinfant bond appears to develop more gradually over the first 2 months' postpartum (Anderson, 1996), and there is evidence for fathers having more difficulties than do mothers with emotional bonding with their infants (Edhborg, Matthiesen, Lundh, \& Widstrom, 2005). For some fathers, the relative slow development of attachment might be related to the father's feeling of helplessness and depression for the first few postpartum months.

Thus, there remains a long list of questions with respect to paternal PPD issues (Schumacher, Zubaran, \& White, 2008) and implications for infant development. Because the existing studies have focused heavily on a Caucasian, middle-class, married fathers, we have a serious lack of understanding about depression of fathers of different cultural and socioeconomic backgrounds. Future studies also must address fathers in nontraditional settings such as stay-at-home fathers, nonbiological fathers (e.g., stepfathers), and single fathers to understand unique risk factors that may increase the risk for paternal PPD and clarify effective treatments and their ideal integration with other services, delivery, and timing.

\section{SOCIAL ISSUES/TREATMENT POSSIBILITIES}

Fathers play important roles in the healthy development of their infants, and paternal depression can disrupt healthy developmental processes. Likewise, paternal support and sensitive coordination with mothers can promote maternal and infant well-being. Given that recent research on the paternal brain has suggested that fathers may more gradually develop a strong attachment with their infants, supported by neurobiological adaptations shaped by interactions with infants, it may be important to examine how the postpartum period might be influenced to optimize paternal development during a critical and protracted period of attachment with their infants. Interventions that enrich paternal social-support networks, minimize stressful interactions with infants and provide expanded opportunities for paternal engagement with their infants, and that promote supportive coparenting with mothers are all possible paths to optimizing paternal and infant neurobiological development.

Many fathers report that they did not learn appropriate parenting skills from their own fathers or other male seniors (Barclay \& Lupton, 1999), and the lack of understanding of what is expected of a father might cause anxiety, especially the first-time fathers, and lead to a greater risk of paternal PPD (Condon, Boyce, \& Corkindale, 2004). Lack of rewards in parenting also might contribute to the development of paternal PPD. Fathers report positive feedback, such as smiles from their infants, as the most significant reward in parenting (Anderson, 1996), but a father's lack of experience in parenting and fewer hours with an infant may tend to make interactions more distressing for the infant. Fathers also report being isolated from mother-infant bonding and feeling jealous about their partners' dominance in spending intimate time with babies, especially through breast-feeding (Goodman, 2002). Fathers report increased dissatisfaction with their relation- ships with their partners, including lack of intimacy (Meighan, Davis, Thomas, \& Droppleman, 1999) and the partner's loss of interest in a sexual relationship (Condon et al., 2004). All of these issues may be subject to specific brain-imaging paradigms involving children for parents, as has been done with nonparents and the social brain, emotion-regulation, and empathy regions. Studying the paternal brain regions that regulate father functioning may constitute a particularly nonstigmatizing way to understand the dynamics.

For fathers, different types of support may ease the transition process to fatherhood during the postpartum period. The most effective supports likely come from their partners because paternal PPD is closely related to partners' mental health and their relationship with the fathers. More encouragement from the mother and active discussion in each couple as they await and prepare for their baby would likely help the father's involvement in parenting and ease stress as a new father. Mothers' sharing parenting roles with them also would lower fathers' feelings of isolation from the relationships between mother-infant as well as difficult feelings such as jealousy toward the infant. Furthermore, supports and acknowledgment from other family members may aid in minimizing difficulties. Thus, educational programs in the community may help fathers understand their expected roles-perhaps with higher attendance if seen as brain programs. Involving both PPD mothers and their partners may be more effective than may approaches to PPD mothers alone (Morgan, Matthey, Barnett, \& Richardson, 1997).

In the transition to parenthood, the quality of the coparenting relationship can impact the quality of both maternal and paternal interaction with their baby. Relationship quality is related to both to mothers' and fathers' ability to coparent effectively as well as father's level of engagement with his child (Carlson, Sroufe, \& Egeland, 2004; Coley \& Chase-Lansdale, 1999). Programs that strengthen coparenting can increase fathers' involvement (Cowan, Cowan, Pruett, Pruett, \& Wong, 2009). Efforts directed at young couples, rather than at just fathers, may be effective since mothers can influence fathers' access to children, especially nonresidential fathers (Knox, Guerra, Williams, \& Toro, 2011) and since couples' interventions can directly address the coparenting relationship. While meta-analyses have supported modest efficacy for relationship-enhancement interventions that improve coparenting and child outcomes (Hawkins et al., 2013; Reardon-Anderson, Stagner, Mocomber, \& Murray, 2005), recent government-supported demonstrations aimed at involving lowincome fathers have delivered only small effects at best (Hawkins et al., 2013; Johnson, 2012) — perhaps for biologically understandable reasons of lacking a brain mechanism and possible poor timing.

Perhaps prenatal interventions aimed at involving expectant fathers may work better as prenatal paternal involvement predicts higher postpartum father engagement with their infants (Cabrera et al., 2008). Engaging fathers at a prenatal ultrasound might be a particularly opportune moment, as attendance by fathers is widespread and as men's responses to the ultrasound visit are 
positive and compelling (Walsh et al., 2014). Likewise, fathers participate at surprisingly high rates in well-child visits for their infants (Davis, Davis, Tolman, Singh, \& Qalsh, in press). Pediatricians can encourage fathers' active involvement, and those visits might be an opportunity to screen fathers as well as mothers for PPD (Garfield \& Fletcher, 2011). Encouraging father to seek help from health professionals for complete assessments and consideration of psychotherapy or antidepressants might significantly improve their family health (Melrose, 2010)_especially in light of advances in mechanistic brain-based understandings of paternal thoughts and behaviors. Indeed, recent brain-imaging studies with mothers have suggested that the capacity of mothers to detect positive versus negative child responses in the frontal cortex is inversely related to stress hormone reactivity (Ho, Konrath, Brown, \& Swain, 2014). This supports the notion that home-visitation programs that engage fathers, foster a positive coparenting relationship, provide support to fathers, and reduce stress also hold promise (Guterman, 2013; Guterman et al., 2013)_-perhaps through identifiable brain pathways.

Support from society, such as paid paternity leave, also may help fathers adapt to changes during the postpartum period, given accumulating evidence that there are benefits to child outcomes of paternity leave. For example, Feldman, Sussman, and Zigler (2004) showed that longer paternal leave is associated with more positive attitude toward parenting. In the United Kingdom, paternity leave has been associated with greater paternal involvement in childcare (Nepomnyaschy \& Garfinkel, 2011). In Scandinavia, greater participation in paternity leave has been associated with better outcomes (lower mortality) for Swedish fathers with depression themselves (Mansdotter \& Lundin, 2010) and, in Norway, improved quality of life (Holter, 2009). As described earlier, the PFC is specifically implicated in paternal mood (Kim et al., 2014), suggesting a future for research on the role of the PFC on mediating the benefits of paid leave, with the intention of optimizing such benefits.

While the interventions and policy recommendations described earlier do not directly derive from current research on the paternal brain, future research might be able to employ newly developed techniques to evaluate the impact of these social and psychological interventions on the brain. This notion is extremely new, with just one study, to our knowledge, on an evidence-based, relationship-focused, psychotherapeutic intervention for traumatized mothers (Swain, Ho, Dayton, Rosenblum, \& Muzik, 2014). In this study, compared to sham wait-list, a parenting intervention aimed at decreasing stress and increasing reflective function was associated with increased emotion-regulation and empathy-circuit brain responses to baby stimuli. Furthermore, increased brain activity in these circuits was associated with decreased parental stress. If confirmed, parallel research on parenting interventions with fathers could help identify the key brain areas both to identify at-risk individuals for more efficient allocation of resources and also to refine the interventions to optimize parenting-brain circuits.

\section{REFERENCES}

Anderson, A.M. (1996). Factors influencing the father-infant relationship. Journal of Family Nursing, 2, 306-324.

Atzil, S., Hendler, T., Zagoory-Sharon, O., Winetraub, Y., \& Feldman, R. (2012). Synchrony and specificity in the maternal and the paternal brain: Relations to oxytocin and vasopressin. Journal of the American Academy of Child \& Adolescent Psychiatry, 51(8), 798-811. doi:10.1016/j.jaac.2012.06.008

Barclay, L., \& Lupton, D. (1999). The experiences of new fatherhood: A socio-cultural analysis. Journal of Advanced Nursing, 29(4), 10131020.

Barrett, J., \& Fleming, A.S. (2011). Annual Research Review: All mothers are not created equal: Neural and psychobiological perspectives on mothering and the importance of individual differences. Journal of Child Psychology and Psychiatry, 52(4), 368-397.

Becker, E.A., Moore, B.M., Auger, C., \& Marler, C.A. (2010). Paternal behavior increases testosterone levels in offspring of the California mouse. Hormones and Behavior, 58(3), 385-389. doi:10.1016/j.yhbeh.2010.03.019

Bester-Meredith, J.K., \& Marler, C.A. (2001). Vasopressin and aggression in cross-fostered California mice (Peromyscus californicus) and white-footed mice (Peromyscus leucopus). Hormones and Behavior, 40(1), 51-64. doi:10.1006/hbeh.2001.1666

Bester-Meredith, J.K., \& Marler, C.A. (2003). Vasopressin and the transmission of paternal behavior across generations in mated, crossfostered Peromyscus mice. Behavioral Neuroscience, 117(3), 455463.

Bowlby, J. (1978). Attachment theory and its therapeutic implications. Adolescent Psychiatry, 6, 5-33.

Boyce, W.T., Essex, M.J., Alkon, A., Goldsmith, H.H., Kraemer, H.C., \& Kupfer, D.J. (2006). Early father involvement moderates biobehavioral susceptibility to mental health problems in middle childhood. Journal of the American Academy of Child \& Adolescent Psychiatry, 45(12), 1510-1520.

Brockington, I. (2004). Postpartum psychiatric disorders. Lancet, 363(9405), 303-310.

Bronfenbrenner, U. (1979). The ecology of human development. Cambridge, MA: Harvard University Press.

Buckner, R.L., Andrews-Hanna, J.R., \& Schacter, D.L. (2008). The brain's default network: Anatomy, function, and relevance to disease. Annals of the New York Academy of Sciences, 1124, 1-38. doi:10.1196/annals.1440.011

Cabrera, N.J., Fagan, J., \& Farrie, D. (2008). Explaining the long reach of fathers' prenatal involvement on later paternal engagement. Journal of Marriage and Family, 70(5), 1094. doi:10.1111/j.17413737.2008.00551.x

Cabrera, N.J., \& Tamis-LeMonda, C.S. (2013). Handbook of father involvement: Multidisciplinary perspectives (2nd ed.). New York: Routledge/Taylor \& Francis.

Carlson, E.A., Sroufe, L.A., \& Egeland, B. (2004). The construction of experience: A longitudinal study of representation and behavior. Child Development, 75(1), 66-83. 
Carson, J., Burks, V., \& Parke, R.D. (1993). Parent-child physical play: Determinants and consequences. In K. MacDonald (Ed.), Parentchild play: Descriptions and implications (pp. 197-220). Albany: State University of New York Press.

Cassidy, J., \& Shaver, P.R. (1999). Handbook of attachment. New York: Guilford Press.

Cavanaugh, J., \& French, J.A. (2013). Post-partum variation in the expression of paternal care is unrelated to urinary steroid metabolites in marmoset fathers. Hormones and Behavior, 63(4), 551-558. doi:10.1016/j.yhbeh.2013.02.006

Cicchetti, D., \& Rogosch, F.A. (2001). Diverse patterns of neuroendocrine activity in maltreated children. Development and Psychopathology, 13(3), 677-693.

Coley, R.L., \& Chase-Lansdale, P.L. (1999). Stability and change in paternal involvement among urban African American fathers. Journal of Family Psychology, 13(3), 416-435.

Condon, J.T., Boyce, P., \& Corkindale, C.J. (2004). The First-Time Fathers Study: A prospective study of the mental health and wellbeing of men during the transition to parenthood. Australian and New Zealand Journal of Psychiatry, 38(1-2), 56-64.

Cowan, P.A., Cowan, C.P., Pruett, M.K., Pruett, K.D., \& Wong, J. (2009). Promoting fathers' engagement with children: Preventive interventions for low-income families. Journal of Marriage and Family, 71(3), 663-679.

Crawley, S.B., \& Sherrod, K.B. (1984). Parent-infant play during the first year of life. Infant Behavior \& Development, 7(1), 65-75. doi:10.1016/S0163-6383(84)80023-5

Davis, R.N., Davis, M.M., Freed, G.L., \& Clark, S.J. (2011). Fathers' depression related to positive and negative parenting behaviors with 1-year-old children. Pediatrics, 127(4), 612-618. doi:10.1542/peds.2010-1779

Davis, R.N., Davis, M.M., Tolman, R.M., Singh, V., \& Qalsh, T. (in press). Expectant fathers' attendance at prenatal ultrasounds. Midwifery. Manuscript submitted for publication.

De Pisapia, N., Bornstein, M.H., Rigo, P., Esposito, G., De Falco, S., \& Venuti, P. (2013). Sex differences in directional brain responses to infant hunger cries. NeuroReport, 24(3), 142-146. doi:10.1097/WNR.0b013e32835df4fa

Dickson, K.L., Walker, H., \& Fogel, A. (1997). The relationship between smile type and play type during parent-infant play. Developmental Psychology, 33(6), 925-933.

Edhborg, M., Matthiesen, A.S., Lundh, W., \& Widstrom, A.M. (2005). Some early indicators for depressive symptoms and bonding 2 months postpartum-A study of new mothers and fathers. Archives of Women's Mental Health, 8, 221-231.

Eiden, R.D., Edwards, E.P., \& Leonard, K.E. (2002). Mother-infant and father-infant attachment among alcoholic families. Development and Psychopathology, 14(2), 253-278.

Featherstone, R.E., Fleming, A.S., \& Ivy, G.O. (2000). Plasticity in the maternal circuit: Effects of experience and partum condition on brain astrocyte number in female rats. Behavioral Neuroscience, 114(1), $158-172$.
Federenko, I.S., \& Wadhwa, P.D. (2004). Women's mental health during pregnancy influences fetal and infant developmental and health outcomes. CNS Spectrums, 9(3), 198-206.

Feldman, R. (2003). Infant-mother and infant-father synchrony: The coregulation of positive arousal. Infant Mental Health Jounal, 24(1), $1-23$.

Feldman, R. (2007). Parent-infant synchrony and the construction of shared timing, physiological precursors, developmental outcomes, and risk conditions. Journal of Child Psychology and Psychiatry, 48(3-4), 329-354.

Feldman, R., Sussman, A.L., \& Zigler, E. (2004). Parental leave and work adaptation at the transition to parenthood: Individual, marital, and social correlates. Journal of Applied Developmental Psychology, 25(4), 459-479.

Feygin, D.L., Swain, J.E., \& Leckman, J.F. (2006). The normalcy of neurosis: Evolutionary origins of obsessive-compulsive disorder and related behaviors. Progress in Neuro-Psychopharmacology and Biological Psychiatry, 30(5), 854-864.

Fleming, A.S., Corter, C., Stallings, J., \& Steiner, M. (2002). Testosterone and prolactin are associated with emotional responses to infant cries in new fathers. Hormones and Behavior, 42(4), 399-413.

Franssen, C.L., Bardi, M., Shea, E.A., Hampton, J.E., Franssen, R.A., Kinsley, C.H., \& Lambert, K.G. (2011). Fatherhood alters behavioural and neural responsiveness in a spatial task. Journal of Neuroendocrinology, 23(11), 1177-1187. doi:10.1111/j.13652826.2011.02225.x

Frazier, C.R., Trainor, B.C., Cravens, C.J., Whitney, T.K., \& Marler, C.A. (2006). Paternal behavior influences development of aggression and vasopressin expression in male California mouse offspring. Hormones and Behavior, 50(5), 699-707. doi:10.1016/j.yhbeh.2006.06.035

Garfield, C.F., \& Fletcher, R. (2011). Sad dads: A challenge for pediatrics. Pediatrics, 127(4), 781-782. doi:10.1542/peds.2011-0097

Gettler, L.T., McDade, T.W., Agustin, S.S., Feranil, A.B., \& Kuzawa, C.W. (2013). Do testosterone declines during the transition to marriage and fatherhood relate to men's sexual behavior? Evidence from the Philippines. Hormones and Behavior, 64(5), 755-763. doi:10.1016/j.yhbeh.2013.08.019

Gettler, L.T., McDade, T.W., Agustin, S.S., \& Kuzawa, C.W. (2011). Short-term changes in fathers' hormones during father-child play: Impacts of paternal attitudes and experience. Hormones and Behavior, 60(5), 599-606. doi:10.1016/j.yhbeh.2011.08.009

Gettler, L.T., McDade, T.W., Agustin, S.S., \& Kuzawa, C.W. (2013). Progesterone and estrogen responsiveness to father-toddler interaction. American Journal of Human Biology, 25(4), 491-498. doi:10.1002/ajhb.22396

Gjerdingen, D.K., \& Center, B.A. (2003). First-time parents' prenatal to postpartum changes in health, and the relation of postpartum health to work and partner characteristics. Journal of the American Board of Family Practice, 16(4), 304-311.

Gleason, E.D., \& Marler, C.A. (2013). Non-genomic transmission of paternal behaviour between fathers and sons in the monogamous 
and biparental California mouse. Proceedings of the Royal Society B: Biolological Sciences, 280(1763), 20130824. doi:10.1098/rspb.2013.0824

Goodman, J.H. (2002). Becoming an involved father of an infant. JOGNNJournal of Obstetric, Gynecologic \& Neonatal Nursing, 34(2), 190200.

Gordon, I., Zagoory-Sharon, O., Leckman, J.F., \& Feldman, R. (2010). Prolactin, oxytocin, and the development of paternal behavior across the first six months of fatherhood. Hormes and Behavior, 58(3), 513518. doi:10.1016/j.yhbeh.2010.04.007

Gray, P.B., Yang, C.F., \& Pope, H.G., Jr. (2006). Fathers have lower salivary testosterone levels than unmarried men and married non-fathers in Beijing, China. Proceedings of the Royal Society B: Biological Sciences, 273(1584), 333-339. doi:10.1098/rspb.2005.3311

Grossmann, K., Grossmann, K.E., Fremmer-Bombik, E., Kindler, H., Scheuerer-Englisch, H., \& Zimmerman, P. (2002). The uniqueness of the child-father attachment relationship: Fathers' sensitive and challenging play as a pivotal variable in a 16-year longitudinal study. Social Development, 11(3), 307-331.

Grossmann, K., Grossmann, K.E., Kindler, H., \& Zimmermann, P. (2008). A wider view of attachment and exploration: The influence of mothers and fathers on the development of psychological security from infancy to young adulthood. In J. Cassidy \& P.R. Shaver (Eds.), Handbook of attachment: Theory, research, and clinical applications (Vol. 2, pp. 857-879). New York: Guilford Press.

Guterman, N.B. (2013). Improving father involvement in early home visiting programs: Early Trends from a pilot intervention study. Paper presented at the 17th annual Conference of the Society for Social Work, January 16-20, San Diego.

Guterman, N.B., Tabone, J.K., Bryan, G.M., Taylor, C.A., NapoleonHanger, C., \& Banman, A. (2013). Examining the effectiveness of home-based parent aide services to reduce risk for physical child abuse and neglect: Six-month findings from a randomized clinical trial. Child Abuse \& Neglect, 37(8), 566-577. doi:10.1016/j.chiabu.2013.03.006

Haig, D. (1999). What is a marmoset? American Journal of Primatology, 49(4), 285-296. doi:10.1002/(SICI)10982345(199912)49:4<285::AID-AJP1>3.0.CO;2-X

Hawkins, A.J., Stanley, S.M., Cowan, P.A., Fincham, F.D., Beach, S.R., Cowan, C.P. et al. (2013). A more optimistic perspective on government-supported marriage and relationship education programs for lower income couples. American Psychologist, 68(2), 110-111. doi: $10.1037 / \mathrm{a} 0031792$

Hedin, L.W. (2000). Postpartum, also a risk period for domestic violence. European Journal of Obstetrics \& Gynecology and Reproductive Biology, 89(1), 41-45.

Ho, S.S., Konrath, S., Brown, S., \& Swain, J.E. (2014). Empathy and stress related neural responses in maternal decision making. Frontiers in Neuroscience, 8, 152. doi:10.3389/fnins.2014.00152

Holter, O.G. (2009). Men, gender and health 2009-The Norwegian view. Journal of Men's Health, 6(2), 101-104.

Hossain, Z., Field, T., Gonzalez, J., Malphurs, J., Del Valle, C., \& Pickens, J. (1994). Infants of "depressed" mothers interact bet- ter with their nondepressed fathers. Infant Mental Health Journal, 15(348-357).

Johnson, M.D. (2012). Healthy marriage initiatives: On the need for empiricism in policy implementation. American Psychologist, 67(4), 296-308. doi:10.1037/a0027743

Kim, P., Leckman, J.F., Mayes, L.C., Feldman, R., Wang, X., \& Swain, J.E. (2010). The plasticity of human maternal brain: Longitudinal changes in brain anatomy during the early postpartum period. Behavioral Neuroscience, 124(5), 695-700.

Kim, P., Mayes, L., Feldman, R., Leckman, J.F., \& Swain, J.E. (2013). Early postpartum parental preoccupation and positive parenting thoughts: Relationship with parent-infant interaction. Infant Mental Health Journal, 34(2), 104-116. doi:10.1002/Imhj. 21359

Kim, P., Rigo, P., Mayes, L.C., Feldman, R., Leckman, J.F., \& Swain, J.E. (2014). Neural plasticity in fathers of human infants. Social Neuroscience, 9(5), 522-535. doi:10.108017470919.2014.933713

Kim, P., \& Swain, J.E. (2007). Sad dads: Paternal postpartum depression. Psychiatry (Edgmont), 4(2), 35-47.

Kinsley, C.H., \& Amory-Meyer, E. (2011). Why the maternal brain? Journal of Neuroendocrinology, 23(11), 974-983. doi:10.1111/j.13652826.2011.02194.x

Kinsley, C.H., \& Lambert, K.G. (2008). Reproduction-induced neuroplasticity: Natural behavioural and neuronal alterations associated with the production and care of offspring. Journal of Neuroendocrinology, 20(4), 515-525. doi:JNE1667[pii]10.1111/j.13652826.2008.01667.x

Kirkpatrick, B., Carter, C.S., Newman, S.W., \& Insel, T.R. (1994). Axon-sparing lesions of the medial nucleus of the amygdala decrease affiliative behaviors in the prairie vole (Microtus ochrogaster): Behavioral and anatomical specificity. Behavioral Neuroscience, 108(3), 501-513.

Knox, L., Guerra, N.G., Williams, K.R., \& Toro, R. (2011). Preventing children's aggression in immigrant Latino families: A mixed methods evaluation of the Families and Schools Together program. American Journal of Community Psychology, 48(1-2), 6576. doi:10.1007/s10464-010-9411-0

Kozorovitskiy, Y., Hughes, M., Lee, K., \& Gould, E. (2006a). Fatherhood affects dendritic spines and vasopressin V1a receptors in the primate prefrontal cortex. Nature Neuroscience, 9(9), 1094-1095. doi: $10.1038 / \mathrm{nn} 1753$

Kozorovitskiy, Y., Hughes, M., Lee, K., \& Gould, E. (2006b). Fatherhood affects dendritic spines and vasopressin V1a receptors in the primate prefrontal cortex. Nature Neuroscience, 9(9), 1094-1095. doi:10.1038/nn1753

Kuo, P.X., Carp, J., Light, K.C., \& Grewen, K.M. (2012). Neural responses to infants linked with behavioral interactions and testosterone in fathers. Biological Psychology, 91(2), 302-306. doi:10.1016/j.biopsycho.2012.08.002

Kuo, P.X., Saini, E.K., Thomason, E., Schultheiss, O.C., \& Volling, B.L. (in press). Individual variation in fathers' testosterone reactivity to infant distress predicts parenting behaviors with 1-year-old infants. Manuscript submitted for publication. 
Lamb, M.E. (1976). The role of the father in child development. New York: Wiley.

Lamb, M.E. (1977). A re-examination of the infant social world. Human Development, 20(2), 65-85.

Lamb, M.E. (2004). The role of the father in child development (4th ed.). New York: Wiley.

Lamb, M.E., Pleck, J.H., Charnov, E.L., \& Levine, J.A. (1985). Paternal behavior in humans. American Zoologist, 25, 883-894. doi:10.1093/icb/25.3.883

Lane, A., Keville, R., Morris, M., Kinsella, A., Turner, M., \& Barry, S. (1997). Postnatal depression and elation among mothers and their partners: Prevalence and predictors. British Journal of Psychiatry, 171, 550-555.

Leckman, J.F., Mayes, L.C., Feldman, R., Evans, D.W., King, R.A., \& Cohen, D.J. (1999). Early parental preoccupations and behaviors and their possible relationship to the symptoms of obsessive-compulsive disorder. Acta Psychiatrica Scandinavica, 100(Suppl. 396), 1-26.

Lonstein, J.S., Simmons, D.A., Swann, J.M., \& Stern, J.M. (1998). Forebrain expression of c-fos due to active maternal behaviour in lactating rats. Neuroscience, 82(1), 267-281.

MacDonald, K. (1987). Parent-child physical play with rejected, neglected, and popular boys. Developmental Psychology, 23(5), 705711. doi:10.1037/0012-1649.23.5.705

Mansdotter, A., \& Lundin, A. (2010). How do masculinity, paternity leave, and mortality associate? A study of fathers in the Swedish parental \& child cohort of 1988/89. Social Science \& Medicine, 71(3), 576-583. doi:10.1016/j.socscimed.2010.05.008

Martins, C., \& Gaffan, E.A. (2000). Effects of early maternal depression on patterns of infant-mother attachment: A meta-analytic investigation. Journal of Child Psychology and Psychiatry and Allied Disciplines, 41(6), 737-746.

Mascaro, J.S., Hackett, P.D., Gouzoules, H., Lori, A., \& Rilling, J.K. (2013). Behavioral and genetic correlates of the neural response to infant crying among human fathers. Social Cognitive and Affective Neuroscience, doi:10.1093/scan/nst166

Mascaro, J.S., Hackett, P.D., \& Rilling, J.K. (2013). Testicular volume is inversely correlated with nurturing-related brain activity in human fathers. Proceedings of the National Academy of Sciences, USA, 110(39), 15746-15751. doi:10.1073/pnas.1305579110

Mascaro, J.S., Rilling, J.K., Negi, L.T., \& Raison, C.L. (2013). Preexisting brain function predicts subsequent practice of mindfulness and compassion meditation. Neuroimage, 69, 35-42. doi:10.1016/j.neuroimage.2012.12.021

Mascaro, J.S., Rilling, J.K., Tenzin Negi, L., \& Raison, C.L. (2013). Compassion meditation enhances empathic accuracy and related neural activity. Social Cognitive and Affective Neuroscience, 8(1), 48-55. doi:10.1093/scan/nss095

Matthey, S., Barnett, B., Howie, P., \& Kavanagh, D.J. (2003). Diagnosing postpartum depression in mothers and fathers: Whatever happened to anxiety? Journal of Affective Disorders, 74(2), 139-147

Meighan, M., Davis, M.W., Thomas, S.P., \& Droppleman, P.G. (1999). Living with postpartum depression: The father's experience. MCN: The American Journal of Maternity/Child Nursing, 24(4), 202-208.
Melrose, S. (2010). Paternal postpartum depression: How can nurses begin to help? Contemporary Nurse, 34(2), 199-210.

Mezulis, A.H., Hyde, J.S., \& Clark, R. (2004). Father involvement moderates the effect of maternal depression during a child's infancy on child behavior problems in kindergarten. Journal of Family Psychology, 18(4), 575-588.

Miller, L.J. (2002). Postpartum depression. Journal of the American Medical Association, 287(6), 762-765.

Morgan, M., Matthey, S., Barnett, B., \& Richardson, C. (1997). A group programme for postnatally distressed women and their partners. Journal of Advanced Nursing, 26, 913-920.

Morse, C.A., Buist, A., \& Durkin, S. (2000). First-time parenthood: Influences on pre- and postnatal adjustment in fathers and mothers. Journal of Psychosomatic Obstetrics and Gynecology, 21(2), 109-120.

Moses-Kolko, E.L., Horner, M.S., Phillips, M.L., Hipwell, A.E., \& Swain, J.E. (2014). In search of neural endophenotypes of postpartum psychopathology and disrupted maternal caregiving. Journal of Neuroendocrinology. doi:10.1111/jne. 12183

Nepomnyaschy, L., \& Garfinkel, I. (2011). Fathers' involvement with their nonresident children and material hardship. Social Service Review, 85(1), 3-38. doi:10.1086/658394

Nunes, S., Fite, J.E., Patera, K.J., \& French, J.A. (2001). Interactions among paternal behavior, steroid hormones, and parental experience in male marmosets (Callithrix kuhlii). Hormes and Behavior, 39(1), 70-82. doi:10.1006/hbeh.2000.1631

Paquette, D. (2004). Theorizing the father-child relationship: Mechanisms and developmental outcomes. Human Development, 47(4), 193-219. doi:10.1159/000078723

Parsons, C.E., Stark, E.A., Young, K.S., Stein, A., \& Kringelbach, M.L. (2013). Understanding the human parental brain: A critical role of the orbitofrontal cortex. Social Neuroscience, 8(6), 525-543.

Paulson, J.F., \& Bazemore, S.D. (2010). Prenatal and postpartum depression in fathers and its association with maternal depression: A metaanalysis. Journal of the American Medical Association, 303(19), 1961-1969.

Paulson, J.F., Dauber, S., \& Leiferman, J.A. (2006). Individual and combined effects of postpartum depression in mothers and fathers on parenting behavior. Pediatrics, 118(2), 659-668.

Pinheiro, R.T., Magalhaes, P.V., Horta, B.L., Pinheiro, K.A., da Silva, R.A., \& Pinto, R.H. (2006). Is paternal postpartum depression associated with maternal postpartum depression? Population-based study in Brazil. Acta Psychiatrica Scandinavica, 113(3), 230 232.

Pleck, J.H. (2010). Paternal involvement: Revised conceptualization and theoretical linkages with child outcome. In M.E. Lamb (Ed.), The role of the father in child development (pp. 58-93). Hoboken, NJ: Wiley.

Polan, H.J., \& Hofer, M.A. (1999). Maternally directed orienting behaviors of newborn rats. Developmental Psychobiology, 34(4), 269 279.

Pruett, K.D. (1998). Role of the father. Pediatrics, 102(5, Suppl. E), 1253 1261. 
Pruett, K.D. (2000). Fatherneed. Why father care is as essential as mother care for your child. New York: Free Press.

Quinlivan, J.A., \& Condon, J. (2005). Anxiety and depression in fathers in teenage pregnancy. Australian and New Zealand Journal of Psychiatry, 39(10), 915-920.

Ramchandani, P.G., O’Connor, T.G., Evans, J., Heron, J., Murray, L., \& Stein, A. (2008). The effects of pre- and postnatal depression in fathers: A natural experiment comparing the effects of exposure to depression on offspring. Journal of Child Psychology and Psychiatry, 49(10), 1069-1078.

Ramchandani, P.G., \& Psychogiou, L. (2009). Paternal psychiatric disorders and children's psychosocial development. Lancet, 374(9690), 646-653. doi:S0140-6736(09)60238-5

Ramchandani, P.G., Stein, A., Evans, J., O'Connor, T.G., \& the Alspac Study Team. (2005). Paternal depression in the postnatal period and child development: A prospective population study. Lancet, 365(9478), 2201-2205. doi:S0140-6736(05)66778-5

Ramchandani, P.G., Stein, A., O'Connor, T.G., Heron, J., Murray, L., \& Evans, J. (2008). Depression in men in the postnatal period and later child psychopathology: A population cohort study. Journal of the American Academy of Child \& Adolescent Psychiatry, 47(4), 390-398.

Reardon-Anderson, J., Stagner, M., Mocomber, J.E., \& Murray, J. (2005). Systematic review of the impact of marriage and relationship programs. Washington, DC: U.S. Department of Health and Human Services, Administration for Children and Families.

Roggman, L.A., Boyce, L.K., Cook, G.A., Christiansen, K., \& Jones, D.K. (2004). Playing with daddy: Social toy play, Early Head Start, and developmental outcomes. Fathering: A Journal of Theory, Research, and Practice about Men as Fathers, 2(1), 83-108.

Rohde, P., Lewinsohn, P.M., Klein, D.N., \& Seeley, J.R. (2005). Association of parental depression with psychiatric course from adolescence to young adulthood among formerly depressed individuals. Journal of Abnormal Psychology, 114(3), 409-420.

Rosenblatt, J.S., \& Ceus, K. (1998). Estrogen implants in the medial preoptic area stimulate maternal behavior in male rats. Hormones and Behavior, 33(1), 23-30.

Ross, C.N., French, J.A., \& Orti, G. (2007). Germ-line chimerism and paternal care in marmosets (Callithrix kuhlii). Proceedings of the National Academy of Sciences, USA, 104(15), 6278-6282. doi:10.1073/pnas.0607426104

Rutter, M., Caspi, A., Fergusson, D., Horwood, L.J., Goodman, R., Maughan, B. et al. (2004). Sex differences in developmental reading disability: New findings from 4 epidemiological studies. Journal of the American Medical Association, 291(16), 2007-2012.

Schore, A.N. (2005). Back to basics: Attachment, affect regulation, and the developing right brain: Linking developmental neuroscience to pediatrics. Pediatrics in Review, 26(6), 204-217.

Schumacher, M., Zubaran, C., \& White, G. (2008). Bringing birth-related paternal depression to the fore. Women and Birth, 21(2), 65-70.

Seifritz, E., Esposito, F., Neuhoff, J.G., Luthi, A., Mustovic, H., Dammann, G. et al. (2003). Differential sex-independent amygdala response to infant crying and laughing in parents versus nonparents. Biological Psychiatry, 54(12), 1367-1375.

Solantaus, T., \& Salo, S. (2005). Paternal postnatal depression: Fathers emerge from the wings. Lancet, 365(9478), 2158-2159.

Soliday, E., McCluskey-Fawcett, K., \& O’Brien, M. (1999). Postpartum affect and depressive symptoms in mothers and fathers. American Journal of Orthopsychiatry, 69(1), 30-38.

St John, W., Cameron, C., \& McVeigh, C. (2005). Meeting the challenge of new fatherhood during the early weeks. Journal of Obstetrics, Gynecologic, and Neonatal Nursing, 34(2), 180-189.

Storey, A.E., Noseworthy, D.E., Delahunty, K.M., Halfyard, S.J., \& McKay, D.W. (2011). The effects of social context on the hormonal and behavioral responsiveness of human fathers. Hormes and Behavior, 60(4), 353-361. doi:10.1016/j.yhbeh.2011.07.001

Storey, A.E., Walsh, C.J., Quinton, R.L., \& Wynne-Edwards, K.E. (2000). Hormonal correlates of paternal responsiveness in new and expectant fathers. Evolution and Human Behavior, 21(2), 79-95.

Swain, J.E. (2009). Brain-based sex differences in parenting propagate emotion expression. Behavioral and Brain Sciences, 32(5), 27-28.

Swain, J.E. (2011). The human parental brain: In vivo neuroimaging. Progress in Neuro-Psychopharmacology and Biological Psychiatry, 35(5), 1242-1254.

Swain, J.E., Ho, S.S., Dayton, C.J., Rosenblum, K.L., \& Muzik, M. (2014). Attachment intervention for trauma-exposed mothers affects stress and empathy neurocircuits. Paper presented at the 34th annual meeting of the Canadian Academy of Child and Adolescent Psychiatry, September 14-16, Toronto.

Swain, J.E., Kim, P., \& Ho, S.S. (2011). Neuroendocrinology of parental response to baby-cry. Journal of Neuroendocrinology, 23(11), 10361041. doi:10.1111/j.1365-2826.2011.02212.x

Swain, J.E., Kim, P., Spicer, J., Ho, S.S., Dayton, C.J., Elmadih, A., \& Abel, K.M. (2014). Approaching the biology of human parental attachment: Brain imaging, oxytocin and coordinated assessments of mothers and fathers. Brain Research. doi:10.1016/j.brainres.2014.03.007

Swain, J.E., Konrath, S., Brown, S.L., Finegood, E.D., Akce, L.B., Dayton, C.J., \& Ho, S.S. (2012). Parenting and beyond: Common neurocircuits underlying parental and altruistic caregiving. Parenting: Science and Practice, 12(2-3), 115-123. doi:10.1080/15295192.2012.680409

Swain, J.E., Leckman, J.F., Mayes, L.C., Feldman, R., Constable, R.T., \& Schultz, R.T. (2003, December). The neural circuitry of parent-infant attachment in the early postpartum. Paper presented at the American College of Neuropsychopharmacology, Puerto Rico.

Swain, J.E., Leckman, J.F., Mayes, L.C., Feldman, R., Constable, R.T., \& Schultz, R.T. (2004). Neural substrates of human parentinfant attachment in the postpartum. Biological Psychiatry, 55, $153 \mathrm{~s}$.

Swain, J.E., Leckman, J.F., Mayes, L.C., Feldman, R., Hoyt, E., Kang, H. et al. (in press). Functional brain activations of parents listening to their own baby-cry change over the early 
postpartum. Developmental Psychobiology. Manuscript submitted for publication.

Swain, J.E., Leckman, J.F., Mayes, L.C., Feldman, R., \& Schultz, R.T. (2005). Early human parent-infant bond development: fMRI, thoughts and behaviors. Biological Psychiatry, 57(8), 112s.

Swain, J.E., \& Lorberbaum, J.P. (2008). Imaging the human parental brain. In R.S. Bridges (Ed.), Neurobiology of the parental brain (pp. 83-100). London: Academic Press.

Swain, J.E., Lorberbaum, J.P., Kose, S., \& Strathearn, L. (2007). Brain basis of early parent-infant interactions: Psychology, physiology, and in vivo functional neuroimaging studies. Journal of Child Psychology and Psychiatry, 48(3-4), 262-287.

Swain, J.E., Mayes, L.C., \& Leckman, J.F. (2004). The development of parent-infant attachment through dynamic and interactive signaling loops of care and cry. Behavioral and Brain Sciences, 27(4), 472-473.

van Anders, S.M., Tolman, R.M., \& Volling, B.L. (2012). Baby cries and nurturance affect testosterone in men. Hormes and Behavior, 61(1), 31-36. doi:10.1016/j.yhbeh.2011.09.012

Vigil, J.M. (2009). A socio-relational framework of sex differences in the expression of emotion. Behavioral and Brain Sciences, 32(5), 375-390; discussion: 391-428. doi:10.1017/S0140525x09991075
Volling, B.L., McElwain, N.L., Notaro, P.C., \& Herrera, C. (2002). Parents' emotional availability and infant emotional competence: Predictors of parent-infant attachment and emerging self-regulation. Journal of Family Psychology, 16(4), 447-465.

Walsh, TB., Singh, V., Davis, R.N., Palladino, C., \& Tolman, R.M. (2014). Moving up the "Magic Moment": Fathers' experience of prenatal ultrasound. Fathering: A Journal of Theory, Research, and Practice about Men as Fathers, 12(1), 18-37.

Wilson, S., \& Durbin, C.E. (2010). Effects of paternal depression on fathers' parenting behaviors: A meta-analytic review. Clinical Psychology Review, 30(2), 167-180.

Wittfoth-Schardt, D., Gründing, J., Wittfoth, M., Lanfermann, H., Heinrichs, M., Domes, G. et al. (2012). Oxytocin modulates neural reactivity to children's faces as a function of social salience. Neuropsychopharmacology, 37(8), 1799-1807. doi:10.1038/npp.2012. 47

Xerri, C., Stern, J.M., \& Merzenich, M.M. (1994). Alterations of the cortical representation of the rat ventrum induced by nursing behavior. Journal of Neuroscience, 14(3), 17101721.

Yogman, M.W. (1981). Games fathers and mothers play with their infants. Infant Mental Health Journal, 2, 241-248. 